\title{
The Effect of Land Use on Soil Organic Carbon Stocks in Lake Victoria Crescent Agro-Ecological Zone, Uganda
}

\author{
David Akodi, Everline Komutunga, Choice Agaba, Kevin John Oratungye and Elizabeth Ahumuza \\ Soils, Agro-Meteorology and Environment Program, National Agricultural Research Laboratories (NARL), Kampala 7065, Uganda
}

\begin{abstract}
The effect of land use on soil organic carbon (SOC) stocks and depth distribution of SOC was investigated in the Lake Victoria Crescent agro-ecological zone of Uganda. Soil samples were collected from six land use types at 0-30, 30-60 and 60-90 cm from profile pits dug in similar soils and slopes. Results indicated that SOC stocks significantly differed across the various land use systems. SOC also varied significantly by depth. The highest SOC and $\mathrm{pH}$ were recorded under natural forest-strict nature. Grassland had the lowest SOC but the highest bulk density (BD). Phosphorous (P) was the highest in banana-coffee systems and the lowest under tea plantations. The lowest values of $\mathrm{pH}$ and $\mathrm{BD}$ were found in highly disturbed natural forest. The upper layers of the soil $(0-30 \mathrm{~cm})$ stored higher amounts of SOC compared to other depths $(30-60 \mathrm{~cm}$ and $60-90 \mathrm{~cm})$. Land use therefore has a significant effect on SOC and other soil physical and chemical properties.
\end{abstract}

Key words: Soil organic carbon, land use change, land use systems, Mabira forest.

\section{Introduction}

Atmospheric greenhouse gases (GHGs), such as carbon dioxide $\left(\mathrm{CO}_{2}\right)$, methane and halocarbons, are the primary contributors to global warming [1-4]. $\mathrm{CO}_{2}$ is the largest emitted GHG in the world today, mainly due to fossil fuel based energy industries and deforestation [5]. Land use changes and forest management activities are among the net sources of $\mathrm{CO}_{2}$ gas to the atmosphere [6]. Deforestation in the tropics alone accounts for about $20 \%$ of total GHGs emissions [7]. Agricultural activities and management practices are also an important anthropogenic driver of GHG emissions [8].

Removing atmospheric carbon and storing it in the terrestrial biosphere is one of the options that have been proposed to compensate for GHG emissions [9]. Other options for mitigation include avoiding emissions, conserving existing carbon pools on land and expanding $\mathrm{C}$ storage in forest ecosystems [6]. Mutuo et al. [10] suggest that there is a need for developing sustainable agricultural systems to

Corresponding author: David Akodi, M.Sc., research field: soil science. maintain and improve soil organic carbon (SOC) content while mitigating land degradation and GHG emissions. Agricultural lands are also believed to be a major potential sink, and could absorb large quantities of carbon if trees and crop plantations are introduced to these systems and judiciously managed [11].

Despite the importance of forest ecosystems and plantation agriculture to carbon sequestration, little is known about amount of carbon sequestered under these land use types and SOC dynamics in the tropics $[12,13]$. Few studies conducted in the East African region have concentrated on the potential of the different land use systems to sequester carbon [11, 14-16], and as such, the question of how land use/land cover change and diversity influence SOC stocks and depth distribution of SOC remains unclear and yet most of the plantations in Uganda have expropriated large areas originally occupied by forests and are continuing to expand.

This study therefore was established to compare the amount of carbon sequestered by the natural forest as well as the neighboring tea estate, sugarcane plantation, plantation forests and annual cropped lands to $90 \mathrm{~cm}$ depth in the Lake Victoria Crescent 
agro-ecological zone in Uganda.

\section{Materials and Methods}

\subsection{Description of the Study Site}

The study was carried out in Mabira Forest and the surrounding agro-ecosystems. Mabira Forest lies in the counties of Buikwe and Nakifuma in Mukono and Buikwe districts. It is situated between $32^{\circ} 52^{\prime}-33^{\circ} 07^{\prime}$ $\mathrm{E}$ and $0^{\circ} 24^{\prime}-0^{\circ} 35^{\prime} \mathrm{N}$ and found $54 \mathrm{~km}$ East of Kampala and $26 \mathrm{~km}$ West of Jinja (Fig. 1). At an average elevation of $1,200 \mathrm{~m}$ above sea level, the temperature is fairly consistent throughout the year, with average daytime and nighttime temperatures of $26{ }^{\circ} \mathrm{C}$ and $16{ }^{\circ} \mathrm{C}$, respectively. The region has two rainy seasons, the first occurring in March to May and the second occurring in September to November with an average monthly rainfall of $149 \mathrm{~mm}$ and $132 \mathrm{~mm}$, respectively. The vegetation is medium altitude moist semi-deciduous forest. The soil types in the reserve and the surrounding areas can be summarized as ferrallitic sandy clay loams with dark clays in the valleys.

\subsection{Soil Sampling}

A total of 42 composite soil samples were randomly collected from three pre-established points across each of six land use systems at three depths (0-30, 30-60 and $60-90 \mathrm{~cm})$. The points were generated using ArcGIS10.1, and the soil samples were collected from these points using a hand held GPS. The six land use systems covered in the research were: (1) cultivated land under rain-fed banana-coffee system; (2) grassland with communal grazing areas; (3) natural forest-buffer, highly disturbed and strict nature zones; (4) plantation forest under pine trees (Pinus caribaea var. hondorensis) for more than 10 years; (5) sugar cane plantation; (6) tea plantation for more than 50 years.

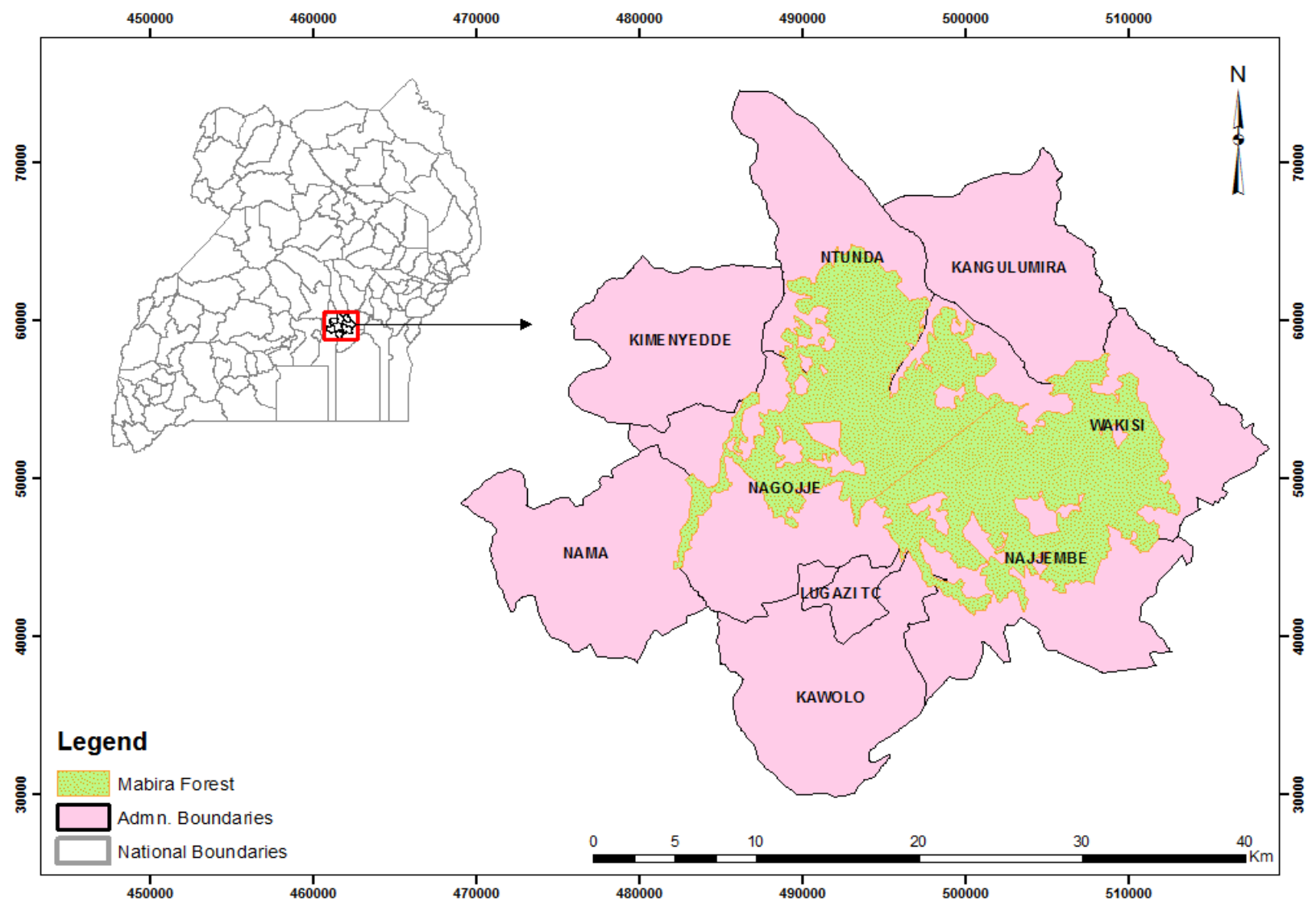

Fig. 1 Location of the study area. 
Undisturbed core samples were collected from the above mentioned depths using a core sampler to determine bulk density (BD). Additionally, the disturbed composite soil samples were collected from the different land use systems for both physical and chemical analysis.

\subsection{Laboratory Analysis}

Soil $\mathrm{pH}$ was measured potentiometrically in a 2.5:1 water to soil suspension, using a combined glass electrode $\mathrm{pH}$ meter. $\mathrm{BD}$ was determined as a ratio of oven-dry soil to its volume [17]. SOC was determined using the wet oxidation method [18] and available $\mathrm{P}$ by Olsen method [19].

\subsection{Statistical Analysis}

SOC stocks over $0-30,30-60$ and $60-90 \mathrm{~cm}$ were calculated as the sum of the SOCs stored in the individual layers from BDs and carbon concentrations for the different layers. One-way analysis of variance ( $F$-test) was used to compare mean carbon across the different land use systems. Following the rejection of the null hypothesis of equality of means at $5 \%$ level of significance, Duncan's multiple range test was used to separate the means. SAS 12 and SPSS 20 were used to run the analyses. Spearman's rank correlation coefficient (non-parametric) was used to determine the relationship between SOC and soil physiochemical properties.

\section{Results}

\subsection{SOC and Other Soil Properties under Different} Land Use Systems

Analysis revealed that mean SOC was significantly different $(P<0.05)$ across the land use systems natural forest-strict nature, natural forest-buffer zone, sugarcane plantation and grassland. However, there was no significant difference $(P>0.05)$ in mean SOC across banana-coffee, tea plantation and sugarcane plantation. SOC under highly disturbed natural forest and pine plantation were not significantly different. SOC was the highest in natural forest-strict nature zone $(147,000 \mathrm{~kg} / \mathrm{ha})$ and the lowest in grassland $(65,000 \mathrm{~kg} / \mathrm{ha})$.

Mean $\mathrm{P}, \mathrm{pH}$ and $\mathrm{BD}$ were significantly different $(P$ $<0.05)$ across all the land use systems. On average, $P$ was the highest under banana-coffee system (6.0 $\mathrm{mg} / \mathrm{kg})$ and the lowest in tea plantations $(0.4 \mathrm{mg} / \mathrm{kg})$. Grasslands on average had the highest value of BD $\left(1.7 \mathrm{~g} / \mathrm{cm}^{3}\right)$, while highly disturbed natural forest had the lowest $\left(1.4 \mathrm{~g} / \mathrm{cm}^{3}\right)$. On average, the highest and the lowest $\mathrm{pH}$ values were recorded under strict nature reserves (5.8) and highly disturbed natural forest (4.67), respectively, as shown in Table 1.

\subsection{Vertical Distribution of SOC}

SOC decreased with increase in depth. There was a significant difference $(P<0.05)$ in mean SOC across different depths $(0-30,30-60$ and 60-90 cm). However, SOC at $30-60 \mathrm{~cm}$ and $60-90 \mathrm{~cm}$ were not significantly different from each other $(P>0.05)$. SOC was the highest in the upper layer of the soil (3.1\%) and the lowest in the $60-90 \mathrm{~cm}$ depth $(1.6 \%)$ as shown in Table 2 and Fig. 2.

Mean $\mathrm{P}$ and BD differed significantly down the soil profile $(P<0.05)$. There was no significant difference in $\mathrm{P}$ and $\mathrm{BD}$ at $30-60 \mathrm{~cm}$ and $60-90 \mathrm{~cm}$ depth. Soil $\mathrm{pH}$ values at different depths were inseparable. Amounts of $\mathrm{P}$ decreased down the soil profile. The highest amount of $\mathrm{P}$ was found in the upper most soil layer $(6.5 \mathrm{mg} / \mathrm{kg})$. BD increased with increase in depth. Soils in the bottom $(60-90 \mathrm{~cm})$ layer had higher BD $\left(1.6 \mathrm{~g} / \mathrm{cm}^{3}\right)$ than soils in the upper and middle layers as indicated in Table 2 .

\subsection{Depth Distribution of SOC by Different Land Use Systems}

There was a decrease in mean SOC down the soil profile across all the land use systems, except for banana-coffee system which had the highest amount of SOC in the 30-60 cm depth as shown in Fig. 2. 
Crescent Agro-Ecological Zone, Uganda

Table 1 SOC and other soil properties under different land use systems.

\begin{tabular}{lllll}
\hline Land use & SOC $\left(\times 10^{3} \mathrm{~kg} / \mathrm{ha}\right)$ & Available P $(\mathrm{mg} / \mathrm{kg})$ & $\mathrm{BD}\left(\mathrm{g} / \mathrm{cm}^{3}\right)$ & $\mathrm{pH}$ \\
\hline Banana-coffee & $95.595^{\mathrm{bc}}$ & $6.044^{\mathrm{a}}$ & $1.491^{\mathrm{b}}$ & $5.733^{\mathrm{a}}$ \\
Natural forest-strict nature & $146.997^{\mathrm{a}}$ & $4.601^{\mathrm{ab}}$ & $1.430^{\mathrm{b}}$ & $5.822^{\mathrm{a}}$ \\
Grassland & $64.734^{\mathrm{d}}$ & $4.383^{\mathrm{ab}}$ & $1.690^{\mathrm{a}}$ & $5.744^{\mathrm{a}}$ \\
Pine plantation & $72.979^{\mathrm{cd}}$ & $3.813^{\mathrm{ab}}$ & $1.451^{\mathrm{b}}$ & $4.711^{\mathrm{bc}}$ \\
Natural forest-buffer zone & $119.246^{\mathrm{b}}$ & $3.388^{\mathrm{abc}}$ & $1.557^{\mathrm{ab}}$ & $5.611^{\mathrm{a}}$ \\
Sugarcane & $95.502^{\mathrm{bc}}$ & $2.469^{\mathrm{bc}}$ & $1.491^{\mathrm{b}}$ & $4.833^{\mathrm{bc}}$ \\
Natural forest-highly disturbed & $77.684^{\mathrm{cd}}$ & $1.794^{\mathrm{bc}}$ & $1.403^{\mathrm{b}}$ & $4.667^{\mathrm{c}}$ \\
Tea plantation & $98.286^{\mathrm{bc}}$ & $0.439^{\mathrm{c}}$ & $1.410^{\mathrm{b}}$ & $5.278^{\mathrm{ab}}$ \\
\hline
\end{tabular}

Means within a column followed by the same letter are not significantly different at $5 \%$ level.

Table 2 SOC, $\mathrm{P}, \mathrm{BD}$ and $\mathrm{pH}$ in different depth distribution of soil.

\begin{tabular}{lllll}
\hline Depth $(\mathrm{cm})$ & SOC $(\%)$ & P $(\mathrm{mg} / \mathrm{kg})$ & $\mathrm{BD}\left(\mathrm{g} / \mathrm{cm}^{3}\right)$ & $\mathrm{pH}$ \\
\hline $0-30$ & $3.106^{\mathrm{a}}$ & $6.459^{\mathrm{a}}$ & $1.317^{\mathrm{b}}$ & $5.417^{\mathrm{a}}$ \\
$30-60$ & $2.000^{\mathrm{b}}$ & $1.831^{\mathrm{b}}$ & $1.552^{\mathrm{a}}$ & $5.037^{\mathrm{a}}$ \\
$60-90$ & $1.609^{\mathrm{b}}$ & $1.654^{\mathrm{b}}$ & $1.603^{\mathrm{a}}$ & $5.446^{\mathrm{a}}$ \\
\hline
\end{tabular}

Means within a column followed by the same letter are not significantly different at $5 \%$ level.

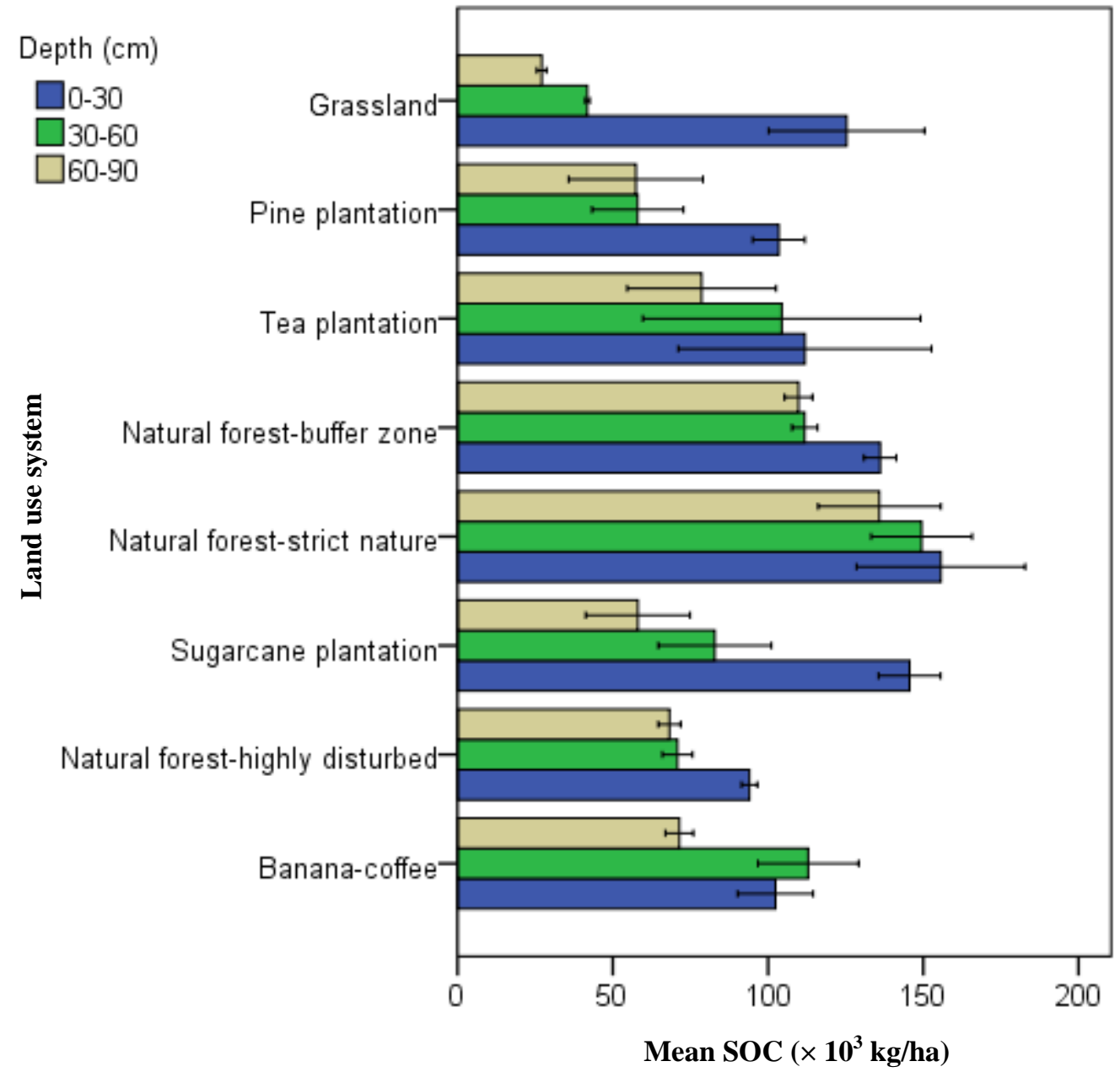

Fig. 2 Depth distribution of SOC by land use type. 

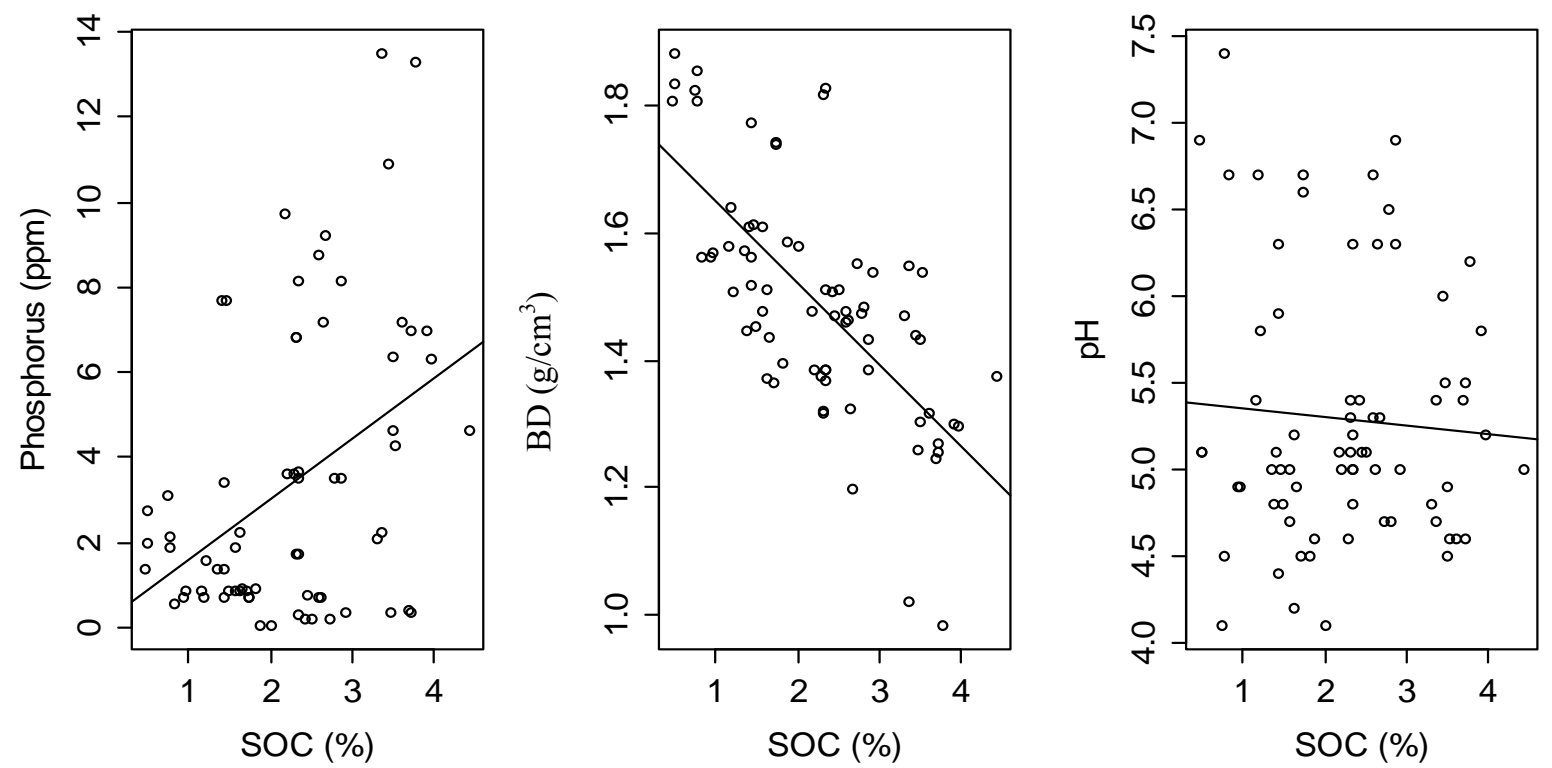

Fig. 3 Relationship between SOC and each of P, BD and pH.

Table 3 Correlation between SOC and each of the parameters $\mathrm{P}, \mathrm{BD}$ and $\mathrm{pH}$.

\begin{tabular}{lllll}
\hline Parameters & & $\mathrm{P}(\mathrm{mg} / \mathrm{kg})$ & $\mathrm{BD}\left(\mathrm{g} / \mathrm{cm}^{3}\right)$ & $\mathrm{pH}$ \\
\hline \multirow{3}{*}{$\mathrm{SOC}(\%)$} & Correlation coefficient & $0.276^{*}$ & $-0.698^{* *}$ & 0.026 \\
& Significance $(P$ value $)$ & 0.021 & 0.000 & 0.828 \\
& Number of pairs & 70 & 72 & 72 \\
\hline
\end{tabular}

${ }^{*}$ Correlation is significant at 0.05 level; ${ }^{* *}$ correlation is significant at 0.01 level.

3.4 Relationship between SOC (\%) and Each of P, BD and $\mathrm{pH}$

SOC was related positively to $\mathrm{P}$ but negatively to $\mathrm{BD}$, and no clear pattern was observed between SOC and $\mathrm{pH}$. There was a weak positive statistically significant relationship between SOC and $\mathrm{P}(P<0.05)$. There was a fairly strong (moderate), negative, statistically significant relationship between SOC and BD $(P<0.05)$. The amount of SOC was found to decline with an increase in BD. There was no evidence of a significant relationship between SOC and $\mathrm{pH}(P>0.05)$ as shown in Fig. 3 and Table 3.

\section{Discussion}

SOC varied significantly by the different land use systems. The highest SOC of 147 ton/ha was recorded under natural forest-strict nature reserves, and the lowest value of 65 ton/ha under grassland. Higher SOC in natural forest-strict nature could be attributed to return of more organic matter from the different tree species (from leaves, barks, fruits and flowers) to the soil. High species richness can initiate complementary resource use between species and enhance productivity leading to greater organic inputs in the forest likely contributing to higher levels of SOC. The present results are in conformity with results obtained in Kenya [15, 20], where higher amounts of SOC were reported in forests ecosystems compared to the surrounding plantations and farmlands. Similar studies conducted in United States of America (USA) and North Belgium also revealed higher amounts of SOC under forests than other land use systems [21].

SOC was more in the upper layers of soil $(0-30 \mathrm{~cm})$ than the deeper layers $(30-60 \mathrm{~cm}$ and $60-90 \mathrm{~cm})$. The variation can be attributed to the vertical distribution of the roots and to a lesser extent to climate and clay content. Climatic condition is also a dominant factor 
determining SOC for the upper soil layer, while for deeper layers, clay content becomes increasingly influential. The study is in agreement with results obtained from studies conducted in Uganda, USA and Germany, where a decrease in SOC was showed down the soil profile [14, 22-24].

The highest value of BD of $1.7 \mathrm{~g} / \mathrm{cm}^{3}$ was recorded under grassland, whereas the lowest value of 1.4 $\mathrm{g} / \mathrm{cm}^{3}$ was recorded under highly disturbed natural forest. This could be attributed to levels of organic matter under the different land use systems and the depth distribution of organic matter, respectively. There were more organic matter in the natural forest ecosystems and the upper layers of soil, which led to better soil structure and hence more porosity. BD increased with increase in depth.

The highest $\mathrm{pH}$ value of 5.8 was found in surface soils under natural forest-strict nature reserves, and the lowest value of 4.67 was recorded under highly disturbed natural forest. Generally, soil $\mathrm{pH}$ values also increased with depth. Soil $\mathrm{pH}$ values ranged from 5.8 to 4.67 , indicating moderately acidic soil conditions under all the land use types. This could be associated with the enhanced leaching of basic cations as well as release of organic acids during mineralization of organic matter.

$\mathrm{P}$ was the highest under banana-coffee system (6.0 $\mathrm{mg} / \mathrm{kg}$ ) and the lowest under tea plantation $(0.4$ $\mathrm{mg} / \mathrm{kg}$ ). P amounts also decreased with increase in depth. The high amounts of $\mathrm{P}$ could be due to application of $\mathrm{P}$ fertilizers, animal manures and decomposition of crop residues. Higher concentration of available $\mathrm{P}$ could also be attributed to higher organic matter content which releases $\mathrm{P}$ during mineralization. The decrease of $\mathrm{P}$ down the soil profile could be due to the increased clay and reduced organic matter content.

\section{Conclusions and Recommendation}

In this study, the current state of SOC under different land use systems was assessed. Results showed that SOC varied significantly by different land use systems. The highest SOC was recorded under natural forest-strict nature reserve and the lowest values under grassland. Both SOC and P were more in the upper layers of soil than the deeper layers. The study also revealed that $\mathrm{P}$ and $\mathrm{BD}$ were higher under banana-coffee system and grassland, respectively. Results of the study therefore offer important directions to follow up research aiming at quantifying the impacts of land use change on SOC and its dynamics. Results from such studies are needed to feed into environmental monitoring plans.

Transparent policies, adequate land use planning and strong policy enforcement should be put in place to conserve natural forest. Further research is needed to quantify the impacts of changes in land use on SOC.

\section{References}

[1] Pfaff, A., Kerr, S., Hughes, F., Liu, S., Sanchéz-Azofeifa, A., Schimel, D., Tosi, J., and Watson, V. 2000. "The Kyoto Protocol and Payments for Tropical Forests: An Interdisciplinary Method for Estimating Carbon-Offset Supply and Increasing the Feasibility of a Carbon Market under the Clean Development Mechanism." Ecological Economics 35 (2): 203-21.

[2] Oliveira, M. E. D., Vaughan, B. E., and Rykle, E. J. 2005. "Ethanol as Fuel: Energy, Carbon Dioxide Balances and Ecological Footprint.” BioScience 55 (7): 593-602.

[3] Intergovernmental Panel on Climate Change (IPCC). 2007. "Summary for Policy Makers." In Climate Change 2007: The Physical Science Basis, edited by Solomon, S., Qin, D., Manning, D., Chen, M. Z., Marquis, M., Averyt, K. B., Tignor, M., and Miller, H. L. Cambridge, UK: Cambridge University Press.

[4] Jacobson, M. Z. 2004. "The Short Term Cooling But Long Term Global Warming due to Biomass Burning." Journal of Climate 17: 2909-26.

[5] Feng, H. L., Zhao, J. H., and Kling, C. 2001. "Carbon: The Next Big Cash Crop?" Choices 16 (2): 16-9.

[6] Dixon, R. K., Brown, S., Houghton, R. A., Solomon, A. M., Trexler, M. C., and Wisniewski, J. 1994. "Carbon Pools and Flux of Global Forest Ecosystems." Science (Washington) 263 (5144): 185-9.

[7] Chomitz, K. M. 2000. "Evaluating Carbon Offsets from Forestry and Energy Projects: How Do They Compare?" 
Accessed November $\quad 10, \quad 2016$. http://documents.worldbank.org/curated/en/16402146873 9158855/116516322_20041117154033/additional/multipage.pdf.

[8] West, T. O., and Marland, G. 2002. "Net Carbon Flux from Agricultural Ecosystems: Methodology for Full Carbon Cycle Analyses.” Environmental Pollution 116 (3): 439-44.

[9] Lal, R. 2002. "Soil Carbon Dynamics in Cropland and Rangeland.” Environmental Pollution 116 (3): 353-62.

[10] Mutuo, P. K., Cadisch, G., Albrecht, A., Palm, C. A., and Verchot, L. 2005. "Potential of Agroforestry for Carbon Sequestration and Mitigation of Greenhouse Gas Emissions from Soils in the Tropics." Nutrient Cycling in Agroecosystems 71 (1): 43-54.

[11] Albrecht, A., and Kandji, S. T. 2003. "Carbon Sequestration in Tropical Agroforestry Systems." Agriculture, Ecosystems \& Environment 99 (1): 15-27.

[12] Powers, J. S., Corre, M. D., Twine, T. E., and Veldkamp, E. 2011. "Geographic Bias of Field Observations of Soil Carbon Stocks with Tropical Land-Use Changes Precludes Spatial Extrapolation." Proc. Natl. Acad. Sci. 108 (15): 6318-22.

[13] Eclesia, R. P., Jobbagy, E. G., Jackson, R. B., Biganzoli, F., and Pineiro, G. 2012. "Shifts in Soil Organic Carbon for Plantation and Pasture Establishment in Native Forests and Grasslands of South America." Global Change Biol. 18 (10): 3237-51.

[14] Grome, T. M. 2010. "Assessment of the Soil Carbon Storage Potential of the Kikonda Reforestation Project, Uganda." Universitätsbibliothek Bodenkultur Wien. Accessed November 2, 2016. http://epub.boku.ac.at/obvbokhs/content/titleinfo/1083487.

[15] Julia, G. 2004. "Preliminary Assessment of Carbon Storage and the Potential for Forestry Based Carbon Based Offset Projects in the Kakamega National Forest, Kenya." Accessed November 2, 2016. http://www.cepf.net/Documents/final.lower.tana.carbon.s torage.pdf.

[16] Munishi, P. K. T., and Shear, T. H. 2004. "Carbon Storage in Afromontane Rain Forests of the Eastern Arc Mountains of Tanzania: Their Net Contribution to Atmospheric Carbon." Journal of Tropical Forest Science 16 (1): 78-93.

[17] Blake, G. R., and Hartge, K. H. 1986. "Particle Density." In Methods of Soil Analysis: Part 1, Physical and Mineralogical Methods, 2nd ed., edited by Klute, A. Madison, USA: American Society of Agronomy, Inc. and Soil Science Society of America, Inc., 377-82.

[18] Walkley, A., and Black, I. A. 1934. "An Examination of the Degtjareff Method for Determining Soil Organic Matter, and a Proposed Modification of the Chromic Acid Titration Method." Soil Science 37 (1): 29-38.

[19] Sahlemedhin, S., and Taye, B. 2000. "Procedures for Soil and Plant Analysis." Technical Paper No. 74, National Soil Research Center, Ethiopian Agricultural Research Organization (EARO), Addis Ababa.

[20] Jepkemei, B. V. 2010. "Potential Economic Value of Carbon Sequestration in Kakamega Forests and Surrounding Farms." Ph.D. thesis, Egerton University.

[21] Schauvlieghe, M., and Lust, N. 1999. "Carbon Accumulation and Allocation after Afforestation of a Pasture with Pine Oak and Ash." Silva Gandavensis 64: $72-81$.

[22] Jobbágy, E. G., and Jackson, R. B. 2000. "The Vertical Distribution of Soil Organic Carbon and Its Relation to Climate and Vegetation." Ecological Applications 10 (2): 423-36.

[23] Lü, X. T., Yin, J. X., Jepsen, M. R., and Tang, J. W. 2010. "Ecosystem Carbon Storage and Portioning in a Tropical Seasonal Forest in Southern China." Forest Ecology and Management 260: 1798-803.

[24] Rhoades, C. C., Eckert, G. E., and Coleman, D. C. 2000. "Soil Carbon Differences among Forest, Agriculture and Secondary Vegetation in Lower Montane Ecuador." Ecological Applications 10 (2): 497-505. 